\title{
EVOLVING LIVESTOCK SECTOR
}

\author{
Fantu Bachewe, Bart Minten, Fanaye Tadesse, \\ and Alemayehu Seyoum Taffesse
}

\section{Introduction}

Ethiopia is home to some of the largest numbers of different livestock species in the world. ${ }^{1}$ For example, the stock of cattle in Ethiopia is the fifth largest in the world, larger than the stocks in important beef producing countries, such as Argentina and Australia (FAO 2018). The value of livestock was evaluated at US\$11 billion in 2015, four times the size of all agricultural exports from the country. Almost all Ethiopian farmers hold some livestock, and it provides for significant employment in rural areas. In short, the animal stocks and the number of people engaged in livestock production indicate that the livestock subsector is a central component of the economy of Ethiopia.

However, livestock production contributed little to the rapid economic growth recorded in the past decade in Ethiopia. While livestock output grew at 5.8 percent per year over the past decade, this was slower than overall GDP growth. Livestock output, therefore, declined in importance. Given this relatively slow growth, the subsector accounted for only 0.5 of the 10.5 percent growth in GDP recorded during the period studied. That is, out of every 100 birr added to the economy, less than 5 birr came from the livestock sector, while crop output growth contributed about five times as much, 24 birr (NBE 2017).

Yet, following the rapid growth in incomes in Ethiopia over the past decade, real expenditure on animal-sourced foods (ASF) and its share in total food spending grew between 2000 and 2011 (Tafere and Worku 2012), partly driven by increases in ASF prices (Chapter 8). Moreover, with further increase in income, ASF are expected to increase in importance, given the changing food preferences of consumers as their incomes increase but also because of the

1 Ethiopia had the largest stock of donkeys in the world in 2016. The stocks of goats and horses are both eighth largest, and those of mules, camels, and sheep ranked fourth, seventh, and ninth, respectively (FAO 2018). 
nutritional benefits of ASF. Furthermore, exports of meat, live animals, and animal products increased in importance from 11 percent of the total value of exports in 2004/2005 to 13 percent in 2015/2016 (NBE 2017). Despite these growing market opportunities and largely untapped resource potentials, livestock production, productivity, and marketed supply remain stagnant.

A number of previous studies investigated different aspects of the livestock subsector in Ethiopia. ${ }^{2}$ Those studies indicate weak institutions, markets, and policymaking, particularly noting the absence of a clear policy framework as an important bottleneck resulting in weak performance of the livestock subsector and market chain. This chapter complements these studies by providing a comprehensive overview of animal-sourced food and live animal production, productivity, and input use at the national level.

This chapter uses descriptive analyses to study the dynamics in the stock of live animals, average holdings, and composition of live animals over the $2004 / 2005$ to $2015 / 2016$ period. It also studies production and productivity of live animals and ASF as well as input use. The chapter relies on econometric analyses to study factors associated with the adoption of modern inputs in livestock production, while a growth accounting method is used to analyze the different sources contributing to growth in real livestock output. For this purpose we use data from the Central Statistical Agency of Ethiopia (CSA) that is representative of mixed crop-livestock farmers in Ethiopia, by far the most important segment of livestock production systems in the country. ${ }^{3}$

We find that recent growth in livestock output came largely from increases in the number of livestock and livestock owners, both of which were over 50 percent higher in 2015/2016 than in 2004/2005, while modern input use and improvements in production methods contributed little. This growth path contrasts with the crop sector where modern input adoption played a large role in recent growth (Bachewe et al. 2018). Given increasing livestock

2 They include studies on livestock production and marketing (Negassa and Jabbar 2008; Negassa, Rashid, and Gebremedhin 2011; Solomon et al. 2003), milk and meat production and marketing (Anteneh et al. 2010), live animal and meat export value chains (Legesse et al. 2008); determinants of herd stocking decisions (Tamirat 2013), livestock holding size and off-take rates (Negassa and Jabbar 2008), characteristics of pastoralist livestock production and marketing (Barrett et al. 2004), and the impacts of risk and wealth on cattle herd size and marketing behavior (Lybbert et al. 2010).

3 Unfortunately, there is a lack of updated representative data on pastoralist livestock systems in the country, so we focus on these mixed systems. In any case, we estimate that the stock of cattle in areas dominated by mixed crop livestock agriculture accounted for more than 90 percent of the nationwide stock in 2015. Similarly, the stock of sheep, goats, equines, and poultry accounted for 78 percent, 63 percent, 93 percent, and more than 97 percent of the nationwide stock of the animals, respectively. 
density per unit of land, we find that feeding practices are changing as access of producers to grazing land is declining. Reliance on commercial feed markets is increasing. Adoption of improved breeds and improved feeds increased rapidly over the past decade, but it started from a low base. Although veterinary service provision also increased considerably, and livestock death rates slightly declined, the number lost to deaths is still more than twice the number sold for meat consumption. Results of the econometric analyses further indicate that adoption of modern inputs in livestock production is positively associated with, among other factors, education level of farmers, access to livestock extension, and proximity to markets and urban centers. Improvements in these factors might therefore help to stimulate modern input adoption in the future. ${ }^{4}$

The remainder of this chapter describes the main dataset used in the study, discusses trends in the numbers and growth rates of livestock, discusses livestock output and productivity, and deals with inputs used in livestock production. The last part of the chapter concludes.

\section{Data Sources and Coverage}

The Central Statistical Agency of Ethiopia (CSA) collects agricultural data in its annual Agricultural Sample Survey (AgSS). The AgSS is conducted through a survey of many households. In an average year during the period covered in this study (2004/2005-2015/2016), 63,000 households were surveyed. Data is collected, among others, on rural households' production of crops and livestock. CSA publishes in its annual statistical reports a summary of these data, which are representative at national, regional, and zonal levels. The data pertain to smallholder farmers, who dominate the Ethiopian agriculture sector. ${ }^{5}$ Our analyses rely on CSA data taken from both household level (raw) data and the statistical reports, while we complement our analyses of these data in this chapter with data from other sources. ${ }^{6}$ Unless indicated

4 With the recent focus of the Ethiopian government on livestock, resulting in a Livestock Sub-ministry being established within the Ministry of Agriculture, Livestock, and Natural Resources, if investments envisaged in the livestock sector roadmap are implemented, livestock production and productivity are expected to improve considerably and make significant contributions to reduction of rural poverty (Shapiro et al. 2015).

5 While several large-scale livestock ranches are being established (see, for example, www .verdebeef.com/), their importance in the national livestock sector is limited.

6 We compare CSA data on live animal stocks with that of FAO (2018) data. The numbers from the two sources are identical in most cases, particularly those since 2009. In only 11 of the 96 cases compared is the number from one source more than 1 percent lower or higher than the 
otherwise, the descriptive analyses presented in this chapter cover the period from 2004/2005 to 2015/2016.

Households in Afar and Somali regions as well as in pastoralist (southern) parts of Oromia rely heavily on livestock production for their livelihood. Consequently, these areas also are home to a considerable proportion of the country's livestock population. Therefore, a study that investigates livestock production in Ethiopia needs to give due attention to these areas. However, during the period covered in this study, the sampling frame of the AgSS excluded the nonsedentary areas of three (of five) zones of Afar and six (of nine) zones of Somali regions (Ethiopia, CSA 2005-2016). CSA collected data on livestock production in the two predominantly pastoralist regions in its pastoralist survey, which was conducted in 2003. However, we do not use that dataset in our analyses for two reasons. First, the data are too outdated to provide timely insights. Second, although the survey covered households in all five zones of Afar, it covered only one zone and left out all six Somali zones not included in the annual AgSS. Therefore, we rely on data from Awsi and Gabi zones in Afar; Siti, Fafan, and Liben zones in Somali; and Borena zone in Oromia, which are covered in CSA's annual AgSS, for our description of pastoralist areas. Using these data, we characterize the pastoralist areas in terms of average livestock ownership and importance in nationwide stock of live animals and animal-sourced food production.

\section{Livestock Size, Composition, and Growth}

We describe trends in the proportions of households that own livestock, and the number, composition, and growth rates of livestock during the 20042015 period.

\section{Number, Structure, and Composition of Livestock}

Data from CSA annual reports between 2005 and 2016 indicate enormous growth in the number of livestock in the country. The data, summarized in Table 5.1, show that the cattle stock in Ethiopia stood at 57.8 million at the end of 2015, 49 percent higher than the number at the end of 2004. The number of sheep in 2015 , about 29 million, increased by 60 percent during the period. The stocks of goats, equines (horses, mules, and donkeys), camels, and poultry

other. We could not do similar comparisons for other variables, as equivalently defined data are unavailable.

7 In the remainder of this chapter we write $2004 / 2005$ as $2004,2015 / 2016$ as 2015 , and so forth. 
TABLE 5.1 Livestock numbers in Ethiopia, by type (2004-2015)

\begin{tabular}{lcccc}
\hline & \multicolumn{3}{c}{ Number (millions) } & \multirow{2}{*}{ Growth rate } \\
\cline { 2 - 4 } Livestock type & 2004 & 2010 & 2015 & 2004-2015 (\%) \\
\hline Tropical livestock units & 34.5 & 48.7 & 54.0 & 56.4 \\
Cattle & 38.7 & 53.4 & 57.8 & 49.4 \\
Sheep & 18.1 & 25.5 & 28.9 & 59.7 \\
Goats & 14.9 & 22.8 & 29.7 & 99.3 \\
Equines & 5.8 & 8.6 & 10.4 & 79.3 \\
Camels & 0.5 & 1.1 & 1.2 & 140.0 \\
Poultry & 30.9 & 49.3 & 60.5 & 95.8 \\
\hline
\end{tabular}

Source: Authors' analyses using CSA data (Ethiopia, CSA 2005-2016).

were 99 percent, 79 percent, 140 percent, and 96 percent higher in 2015 than in 2004, at which time the stocks were 14.9, 5.8, 0.5, and 30.9 million, respectively.

Most Ethiopian farmers own livestock. About 92 percent of farm households surveyed owned at least one type of livestock in 2015 (Table 5.2). Cattle are the most common livestock owned, followed by poultry. The trend in the proportion that owned at least one type of livestock remained about the same during the period. However, the absolute number of livestock-owning households increased by about 51 percent, from 10.3 million in 2004 to 15.5 million in 2015. The trend was also similar for the proportion that owned each livestock species, except for a slight increase in the proportion owning camels and equines, mainly donkeys.

Considering households that own livestock, the average number of cattle and chickens owned was the highest at about four head per household in 2015 (Table 5.2). Yet the average number of equines and camels owned was less than one. Except for a slight increase in goats and poultry, there was no notable variation in average livestock ownership over the years. Most of the increase in livestock numbers seems to have come from an increase in the number of households owning livestock.

Table 5.2 also provides information on the composition of the livestock owned by households - the contribution of each livestock type to the total tropical livestock units (TLUs) owned by households. ${ }^{8}$ An average household owned around 3.7 TLUs in 2015. Total TLU increased by 56.4 percent or an

8 TLU normalizes the number of livestock into camel units. It is computed using the formula: $\mathrm{TLU}=$ camels $+\left(0.7^{*}\right.$ cows $)+\left(0.8^{*}\right.$ horses $)+\left(0.5^{*}\right.$ donkeys $)+\left(0.5^{*}\right.$ mules $)+\left(0.1^{*}\right.$ sheep $)+$ $\left(0.1^{*}\right.$ goats $)+\left(0.01^{*}\right.$ chickens $)$. 
TABLE 5.2 Livestock ownership and composition in Ethiopia, by type (2004-2015)

\begin{tabular}{|c|c|c|c|c|c|c|c|c|c|}
\hline \multirow[b]{2}{*}{ Livestock type } & \multicolumn{3}{|c|}{$\begin{array}{l}\text { Households that own } \\
\text { livestock (\%) }\end{array}$} & \multicolumn{3}{|c|}{$\begin{array}{l}\text { Average livestock } \\
\text { owned, head count, } \\
\text { among owners }\end{array}$} & \multicolumn{3}{|c|}{$\begin{array}{l}\text { Livestock composition, } \\
\text { percent of tropical } \\
\text { livestock units }\end{array}$} \\
\hline & 2004 & 2010 & 2015 & 2004 & 2010 & 2015 & 2004 & 2010 & 2015 \\
\hline All livestock & 92.6 & 92.9 & 92.3 & - & - & - & - & - & - \\
\hline Cattle & 82.3 & 82.1 & 79.7 & 4.0 & 4.0 & 3.9 & 73.1 & 71.7 & 68.7 \\
\hline Sheep & 35.7 & 36.0 & 35.2 & 1.9 & 1.9 & 2.0 & 7.2 & 7.4 & 7.6 \\
\hline Goats & 27.4 & 27.5 & 27.7 & 1.5 & 1.7 & 2.0 & 5.6 & 5.7 & 6.1 \\
\hline Equines & 33.9 & 37.3 & 41.3 & 0.6 & 0.7 & 0.7 & 8.3 & 9.2 & 10.7 \\
\hline Camels & 1.0 & 1.4 & 1.7 & 0.1 & 0.1 & 0.1 & 0.4 & 0.5 & 0.6 \\
\hline Poultry & 57.2 & 58.3 & 58.3 & 3.2 & 3.7 & 4.0 & 5.5 & 5.5 & 6.3 \\
\hline
\end{tabular}

Source: Authors' analyses using CSA holder-level data (Ethiopia, CSA 2017).

Note: $-=$ data not available.

average annual rate of 4.2 percent during the period. In 2015 cattle and small ruminants (sheep and goats) accounted for around 69 percent and 14 percent of the total TLUs, respectively. The composition of TLU changed little between 2004 and 2015; notable changes include a decline in the contribution of cattle to total TLU by 4.0 percent and an increase in equines to total TLU by 2.4 percent.

We further measure the real value of the stock of livestock in the country using data on producer prices of livestock collected by CSA (Ethiopia, CSA 2017) and data on the number of livestock. We also use zonal numbers of livestock to weight the importance of each zone in the real price of each type of livestock. 'The real value of livestock type $x$ in a given year is computed as a multiple of the number of livestock type $x$ in that year and its weighted average price in December 2011. We use the US dollar-to-birr exchange rate in December 2011 to convert that value to US dollars.

We provide a summary of these computations in Table 5.3. In 2004 the stock of livestock in the zones covered by the CSA data were worth 121.2 billion birr (in December 2011 prices). This grew to 192 billion birr (US $\$ 11.2$ billion) in 2015. That is, the real value of livestock grew by 58.4 percent or an average annual rate of 4.3 percent, which is close to the growth rate of livestock size measured in TLU. Growth in real value was

9 The weights ensure that zones with unduly high or low prices but with relatively few livestock do not overly influence prices. Each administrative zone's weight in livestock type $x$ price is computed for each year as: weight $=$ (number of $x$ in zone/total number of $x$ nationally). Then for each zone we take as the weight the average of the weights so computed. 
TABLE 5.3 Real value of the stock of live animals in Ethiopia, December 2011 prices

\begin{tabular}{lccccccccc}
\hline & \multicolumn{2}{c}{ Value (billions) } & & \multicolumn{4}{c}{ Share out of real value of livestock (\%) } \\
\cline { 2 - 7 } \cline { 6 - 9 } Year & birr & US\$ & & Cattle & Sheep & Goats & Equines & Camels & Poultry \\
\hline 2004 & 121.24 & 7.1 & & 77.8 & 6.5 & 5.8 & 7.1 & 1.6 & 1.2 \\
2010 & 171.67 & 10.0 & & 75.9 & 6.5 & 6.3 & 7.2 & 2.7 & 1.4 \\
2015 & 192.03 & 11.2 & & 74.4 & 6.6 & 7.4 & 7.5 & 2.6 & 1.5 \\
\hline
\end{tabular}

Source: Authors' analyses using CSA data (Ethiopia, CSA 2005-2016, 2017).

lowest in cattle ( 52 percent) and sheep ( 60 percent), while it was highest for goats (100 percent) and camels (168 percent). The contribution of each livestock species remained about the same during the period. However, the lower growth rate in the real value of cattle is reflected in the decline in the share of cattle in the total real value of livestock. The rapid growth in the real value of goats and camels is reflected in the higher increase in the share of the animals in real value of livestock.

\section{Livestock Stocks in the Pastoralist Areas of Ethiopia}

We summarize CSA data on livestock ownership in the six pastoralist zones in Table 5.4. Almost all households in the six pastoralist zones owned livestock in 2015. The proportion of pastoralist households that owned cattle was 83 percent in 2004, but this declined to 69 percent in 2015. The proportion that owned sheep, goats, camels, and poultry in 2015 was 53 percent, 67 percent, 25 percent, and 22 percent, respectively. The data indicate that the proportion of pastoralist farmers that owned cattle and poultry in 2015 was 15 percent and 18 percent lower, respectively, relative to 2004, while the proportion that owned sheep, goats, and camels increased by 15 percent, 5 percent, and 6 percent, respectively. This indicates that pastoralists are shifting away from cattle and poultry, focusing more on camels and small ruminants (see, for example, Aklilu and Catley 2010).

Cattle ownership per household averaged 5.4 in 2015, which was 1.5 lower than that in 2004. In contrast, sheep, goat, and camel ownership in 2015 was 3.0, 4.5, and 0.4, respectively, higher than average ownership in 2004, which reinforces the observation that pastoralist farmers may be shifting toward camels and small ruminants. The six pastoralist zones accounted for 4.7 percent of the total number of cattle in Ethiopia in 2015, but accounted 
TABLE 5.4 Livestock ownership by type, pastoralist areas in Ethiopia (2004-2015)

\begin{tabular}{|c|c|c|c|c|c|c|c|c|c|}
\hline \multirow[b]{2}{*}{ Livestock type } & \multicolumn{3}{|c|}{$\begin{array}{l}\text { Households that own } \\
\text { livestock (\%) }\end{array}$} & \multicolumn{3}{|c|}{$\begin{array}{l}\text { Average livestock } \\
\text { owned, head count, } \\
\text { among owners }\end{array}$} & \multicolumn{3}{|c|}{$\begin{array}{l}\text { Livestock composition, } \\
\% \text { of tropical } \\
\text { livestock units }\end{array}$} \\
\hline & 2004 & 2010 & 2015 & 2004 & 2010 & 2015 & 2004 & 2010 & 2015 \\
\hline All livestock & 96.1 & 94.3 & 96.1 & - & - & - & - & - & - \\
\hline Cattle & 83.4 & 73.4 & 68.7 & 6.9 & 6.7 & 5.4 & 4.8 & 4.9 & 4.7 \\
\hline Sheep & 38.3 & 46.0 & 53.2 & 3.1 & 5.9 & 6.1 & 4.7 & 9.2 & 10.5 \\
\hline Goats & 61.6 & 61.9 & 66.8 & 6.8 & 10.0 & 11.3 & 12.3 & 17.4 & 19.4 \\
\hline Equines & 36.3 & 33.4 & 34.8 & 0.6 & 0.6 & 0.6 & 2.9 & 2.9 & 2.9 \\
\hline Camels & 18.9 & 22.5 & 24.9 & 1.2 & 2.0 & 1.6 & 71.3 & 70.8 & 67.8 \\
\hline Poultry & 39.5 & 29.1 & 21.8 & 2.3 & 2.0 & 1.7 & 2.0 & 1.6 & 1.4 \\
\hline
\end{tabular}

Source: Authors analyses using CSA holder level data (Ethiopia, CSA 2017).

Note: $-=$ data not available.

for nearly 11 percent, 20 percent, and 68 percent of the total number of sheep, goats, and camels, respectively.

We further estimate the contribution of all pastoralist zones (including those not in the AgSS data) to the total stock of animals in Ethiopia under the simple assumption that the stock of each animal species in each of the zones in Afar and Somali regions not covered in CSA's AgSS is equal to the average of the stocks in the zones covered in the AgSS. ${ }^{10}$ Under this assumption the cattle stock in pastoralist areas-that is, Afar and Somali regions and the Borana zone in Oromia region-accounted for 9.6 percent of the nationwide stock of cattle in the country in 2015. Similarly, the share of the national stock of sheep, goats, and camels in the pastoralist areas is estimated at 22 percent, 37 percent, and 84 percent, respectively.

\section{Livestock Technical Performance}

Two important livestock technical performance parameters are annual death rates and annual growth rates. These parameters are measured by looking at retrospective 12-month recall data for each of the years considered in the study. The annual death rate of each livestock type is calculated by dividing

10 Average livestock holdings of farmers in nonsedentary parts of Afar and Somali regions is likely to be higher than those in sedentary parts. However, since the nonsedentary parts are sparsely populated, we assume that the two effects cancel each other. 


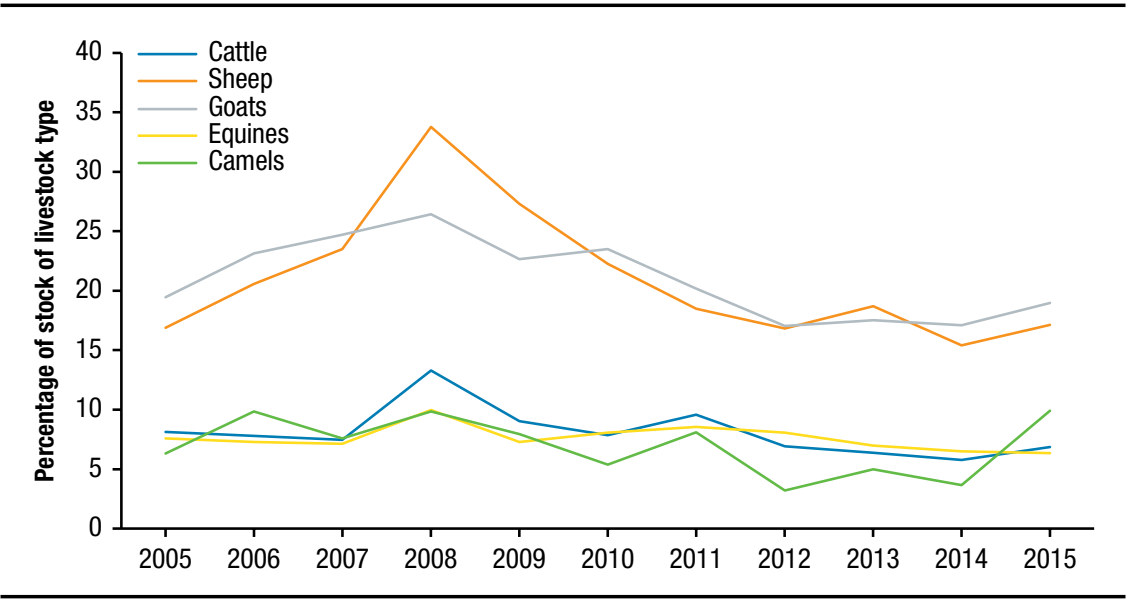

Source: Authors' analyses using CSA holder-level data (Ethiopia, CSA 2017).

the total number of deaths by the average stock of that livestock type. ${ }^{11}$ CSA data indicate that livestock death rates generally increased between 2004 and 2008, when there was a spike in death rates of all species but has generally declined since (Figure 5.1). Average death rates during the 2005-2015 period were close for cattle, equines, and camels at around 7 percent, while they were higher at about 20 percent for sheep and goats. Relative to 2005, death rates in 2014 were about 1 percent lower for sheep and equines, 2 percent lower for cattle and goats, and 3 percent lower for camels.

Annual growth rate in the aggregate stock of each livestock type is calculated by dividing the difference between the ending and beginning stocks by the beginning stock of that individual animal. Growth rates have been positive for all livestock species in most years (Table 5.5). This excludes sheep and

11 This number includes livestock deaths due to diseases or other reasons and does not include slaughters. 
camels, in which negative growth rates were observed in four of the 11 years. However, average annual growth rates were positive for all livestock species. Average annual growth rate was the lowest for cattle at 3.8 percent, while it was the highest for camels at 9.4 percent. Growth averaged 4.6 percent, 5.6 percent, 6.6 percent, and 6.7 percent for sheep, equines, poultry, and goats, respectively.

\section{Livestock and Animal-Sourced Food Production and Productivity}

Livestock serve a multitude of purposes, including, among others, providing food for farm households, being sold when the household is in need of money, and being used to plow the land used in crop production. Consequently, livestock constitute an important source of income for farm households and ultimately for the national economy. For example, livestock income accounted for 11 percent of the total income of rural households in the Agricultural Growth Program baseline survey datset, which included 93 woredas in Tigray, Amhara, Oromia, and Southern Nations, Nationalities, and Peoples (SNNP) regions (Chapter 11). When this analysis is expanded to include households in Afar, Somali, Gambella, and Benishangul-Gumuz regions, other regions in which livestock production is important, the share of livestock income is significantly higher at 21 percent.

The livestock subsector has historically been an important input supplier for Ethiopia's manufacturing sector. Established in the mid-1920s, leather processing and leather articles producing firms were among the earliest manufacturing enterprises in Ethiopia (Oqubay 2015). However, over many years the performance of the leather processing and leather products manufacturing subsector remained poor and thus was unable to take advantage of the rich primary inputs Ethiopia's livestock subsector could provide (Oqubay 2015). However, the contribution of the livestock subsector to the manufacturing sector is expected to grow following recent improvements in the leather processing and manufacturing, meat processing, and dairy processing subsectors (AACCSA 2015, 2016).

Next we discuss trends in animal-sourced food production, specifically of milk and eggs, and productivity and trends in livestock used in meat production (net commercial off-take). Trends in real output and productivity are also discussed. Finally, results of growth accounting analyses conducted to analyze the sources of growth in real livestock output are discussed. 


\section{Milk and Egg Production and Productivity}

Total milk production increased by about 41 percent between 2005 and 2015, while growth in egg production was 84 percent over the same period (Figure 5.2). ${ }^{12}$ Despite the significant growth in outputs, milk and egg productivity (output per animal) stagnated during the period. Milk and egg productivity in 2015 were 5 percent and 8 percent lower than in 2005, respectively. Figure 5.2 indicates that there were no significant changes in productivity during the interim period. The stagnant productivity per animal implies that the rapid growth in output resulted from the increase in the number of livestock and livestock farmers, a claim corroborated by the growth accounting analyses discussed below.

Milk production of the six pastoralist zones accounted for about 12 percent of the national milk production in both 2005 and 2015. The contribution of these zones toward nationwide egg production has been less than 3 percent in all years studied and has generally declined. This is consistent with the summary in Table 5.4, which shows a decline in the share of farmers owning poultry and average ownership of poultry in pastoralist areas.

We use FAO (2018) data to compare milk productivity in Ethiopia with countries at similar and higher levels of development (Figure 5.3). Out of countries depicted, milk yields in Ethiopia are higher only than those of Nigeria. Other countries with lower milk yields than Ethiopia's include Bangladesh, Ghana, Senegal, and several other West African countries, while yields in all East African countries are higher than Ethiopia's. Milk yields in Uganda, Kenya, and Malawi in 2014 were 27 percent, 125 percent, and 239 percent higher, respectively, than yields in Ethiopia, while yields in the Asian countries were at least five times higher. Perhaps more important is the fact that milk productivity is stagnant in Ethiopia. While milk yields in 2014 were lower than in 2004 in Ethiopia and Uganda and grew only marginally in Nigeria, growth rates in the remaining countries and regions over this period were considerable. While these numbers indicate the opportunities in milk production of which Ethiopia can take advantage, they also indicate the scope of the challenges to increase productivity to levels observed in other regions.

12 Annual growth in milk and egg output averaged about 3.8 percent and 6.4 percent, respectively. 
FIGURE 5.2 Milk and egg production and productivity, 2005-2015

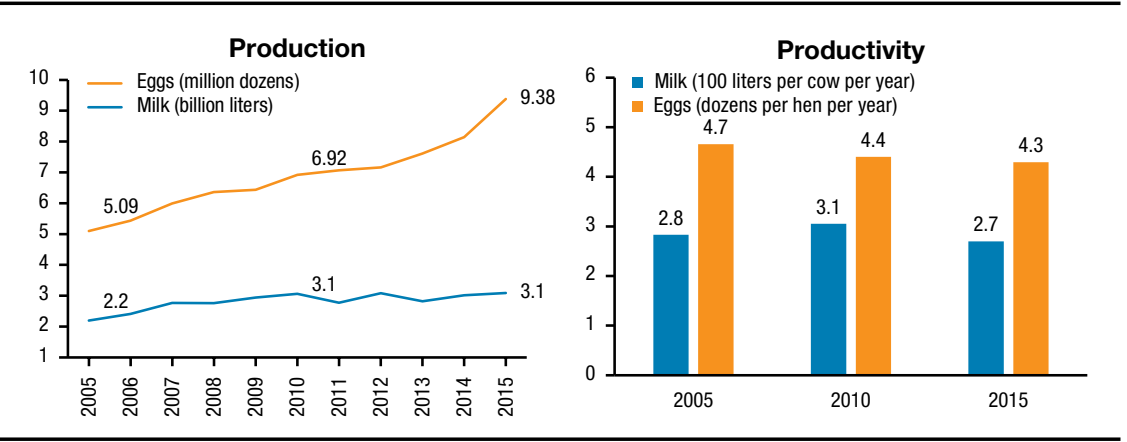

Source: Authors' analyses using CSA data (Ethiopia, CSA 2017).

FIGURE 5.3 International comparison of milk productivity, 2014 (kilograms per cow)

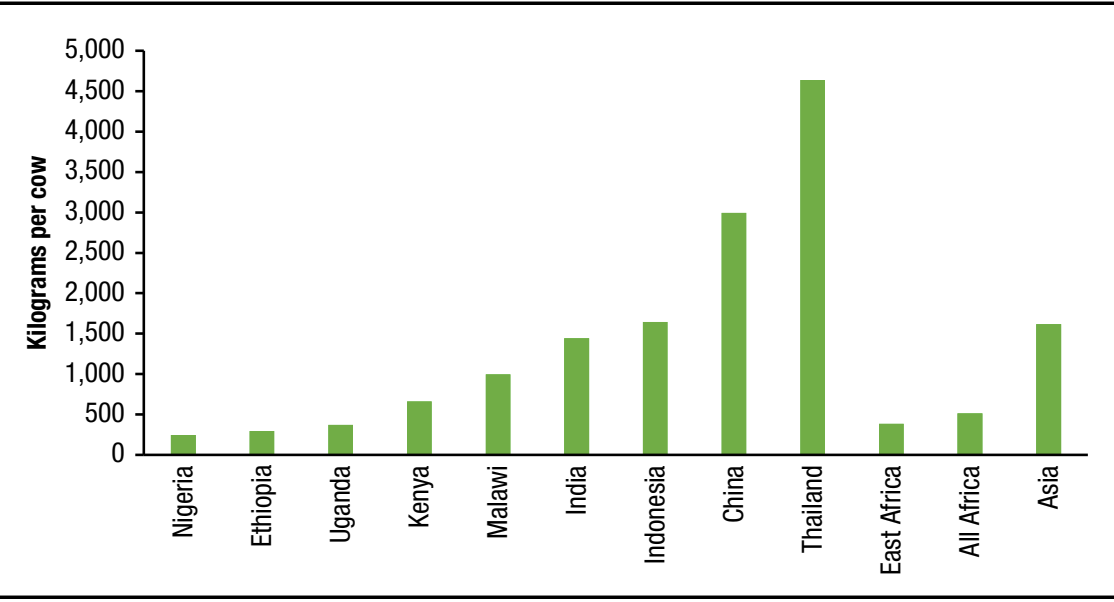

Source: Authors' analyses using FAO (2018) data.

Note: The numbers for East Africa, All Africa, and Asia pertain to 2012.

\section{Meat Production and Exports: Net-Commercial Off-Take}

The meat production capacity of the livestock subsector can be directly influenced by the number of live animals produced for such purposes as well as by the quantity of meat per animal produced. This section discusses the netcommercial off-take (NCOT) rates of livestock, while productivity in terms of meat per animal is discussed next. The NCOT rate is essentially the rate at which livestock leave the farm ultimately for use in meat production or for live exports. While the NCOT rate shows the net market position of households 
for each livestock type, we also discuss below three related (gross) market participation rates: sales off-take, slaughter off-take, and commercial intake (purchase) rates.

Results of computations of gross and net commercial market participation rates are presented in Table 5.6. Poultry has the highest sales off-take rate, followed by sheep, goats, and cattle, while camels have the lowest sales off-take rates. The proportion sold increased over the period for all animals, except equines, although the increase was generally low. The highest increase was observed for cattle and goats at 1.7 percent.

Chicken had the highest slaughter off-take rate of 28 percent in 2015 (Table 5.6). The second and third most slaughtered animals are sheep and goats, respectively. Cattle and camels are the least slaughtered animals. The proportion of slaughtered cattle changed little over the years. The proportion increased by more than 4 percent for chicken and by about 2 percent for small ruminants, but it declined for camels.

The livestock commercial purchase rate in 2015 was the highest for chickens ( 20 percent), followed by sheep ( 16 percent) and equines ( 10 percent), while it is the lowest for camels at 4 percent. The commercial intake rate has shown a slight decline over the period for all livestock types, except for cattle and poultry. In 2015 the net-commercial off-take (NCOT) rate was only 3.3 percent for cattle while it was higher at 7.7 percent, 9.7 percent, and 6.8 percent for sheep, goats, and poultry, respectively. The net market position in 2015 was 1 percent higher than in 2004 for cattle. It increased by nearly 2 percent for goats, was stagnant for sheep, and declined by about 2 percent for poultry.

Considering the six pastoralist zones, average NCOT rate of cattle was 5 percent in 2004 and 7 percent in 2015. These are higher than twice the corresponding national rates in Table 5.6. Similarly, the NCOT rates of sheep and goats were about the same at 17 percent for pastoralist areas in 2015, which is considerably higher than the nationwide rate. Looking into the numbers that constitute the NCOT rate reveals that, while sales rates in pastoralist areas are about the same as in other parts of the country, the higher NCOT rates in pastoralist areas are mainly due to relatively lower purchase rates in such areas.

The foregoing discussion indicates that growth in the NCOT rate or in the proportion of live animals sold for use in meat production has generally been low. The latter, together with the rapid increase in the real price of meat observed in the country during the period (see Chapter 8) imply, among 
TABLE 5.6 Proportion of livestock sold, slaughtered, and purchased in Ethiopia, by type (\%)

\begin{tabular}{|c|c|c|c|c|c|c|c|c|c|c|c|c|}
\hline \multirow[b]{2}{*}{ Livestock type } & \multicolumn{3}{|c|}{ Sales } & \multicolumn{3}{|c|}{ Slaughters } & \multicolumn{3}{|c|}{ Purchases } & \multicolumn{3}{|c|}{$\begin{array}{l}\text { Net commercial } \\
\text { off-take (NCOT) }\end{array}$} \\
\hline & 2005 & 2010 & 2015 & 2005 & 2010 & 2015 & 2005 & 2010 & 2015 & 2005 & 2010 & 2015 \\
\hline Cattle & 9.4 & 10.6 & 11.1 & 0.7 & 0.8 & 0.9 & 7.3 & 7.9 & 8.1 & 2.4 & 3.0 & 3.3 \\
\hline Sheep & 23.4 & 22.6 & 23.5 & 10.2 & 12.7 & 12.2 & 16.5 & 15.1 & 16.1 & 7.4 & 8.0 & 7.7 \\
\hline Goats & 16.5 & 20.6 & 18.2 & 6.6 & 8.8 & 8.2 & 9.2 & 8.6 & 8.7 & 8.0 & 12.6 & 9.7 \\
\hline Equines & 8.0 & 7.0 & 6.3 & - & - & - & 12.0 & 11.7 & 10.4 & -4.0 & -4.7 & -4.1 \\
\hline Camels & 4.3 & 6.5 & 4.9 & 1.5 & 0.9 & 0.3 & 4.4 & 4.3 & 3.7 & 1.4 & 3.0 & 1.5 \\
\hline Poultry & 24.0 & 24.5 & 25.4 & 24.1 & 26.6 & 28.4 & 16.6 & 18.5 & 20.0 & 8.7 & 7.3 & 6.8 \\
\hline
\end{tabular}

Source: Authors' analyses using CSA holder-level data (Ethiopia, CSA 2017).

Note: $-=$ data not available.

others, that growth in the supply of livestock put to such uses was slower relative to growth in demand for meat. In other words, productivity in livestock produced for meat production grew slower than demand during the period studied.

\section{Meat Productivity}

We investigate trends in meat productivity per animal in Ethiopia using data from the Food and Agriculture Organization of the United Nations (FAO 2018). The data indicate that meat yield (carcass weight) per animal changed little between 2004 and 2014, the latest year for which data are available. Average meat yields of sheep, goats, poultry, and camels was the same during the entire period at 10 kilograms, 8.5 kilograms, 0.8 kilograms, and about 170 kilograms per animal, respectively (FAO 2018). Carcass weights for cattle were between 108.0 kilograms and 109.2 kilograms during the period. ${ }^{13}$

Data to triangulate the numbers on meat productivity per animal from FAO are unavailable. Nonetheless, we suspect meat productivity per animal may not have remained constant between 2004 and 2014 but may have increased, at least for poultry and cattle. This follows from CSA (Ethiopia, CSA 2017) data that shows increased adoption of hybrid and foreign poultry by smallholders, from the increasing number in Ethiopia of modern poultry farms (NABC 2011) that produce larger chicken varieties, and focus-group discussions conducted by the authors indicating increases in the number of

13 It is not very clear what data collection processes the FAO has used to come to these estimates. 
institutions that fatten cattle for live exports and for domestic butcheries selling premium quality beef. However, whether and by how much these improvements have impacted meat yields needs to be empirically assessed.

\section{Real Livestock Output and Productivity}

In addition to producing eggs and milk and being used in meat production, livestock provide other services. Most notably, farmers use cattle to plow land used in crop production and as insurance against unexpected cash needs. ${ }^{14}$ The production and productivity measures discussed so far ignore such services of livestock. We provide two additional measures of livestock productivity that account for most outputs or services of livestock. We use data from the National Bank of Ethiopia (NBE) on the real value of livestock output. We proxy labor productivity in the livestock subsector by dividing the real value of livestock output (NBE 2017) by the total number of livestock farmers (Ethiopia, CSA 2017). Similarly, the real productivity of livestock is estimated by dividing real livestock output by the total tropical livestock units (Ethiopia, CSA 2005-2016).

NBE (2017) data indicate that real livestock output in 2015 (53.4 billion birr, in December 2011 prices) was 73 percent higher than in 2004 ( 30.9 billion birr), and growth in real output averaged 5.1 percent per year. Real livestock output per TLU was 894 birr in 2004 and 990 birr in 2015, which indicates a total growth in livestock output per TLU of 10.7 percent and annual growth in livestock output per TLU of 1 percent per year (Figure 5.4). Similarly, real output per livestock farmer grew at an average annual rate of 1.3 percent for total growth of 15 percent from 2,996 birr in 2004 to 3,443 birr in 2015 .

\section{Livestock Output Growth Accounting}

This section discusses the results of a growth accounting analyses of Ethiopia's livestock subsector. The analysis, which uses a modified growth accounting model (Solow 1957), decomposes growth in real value of livestock output into changes in input use, exogenous factors that affect output growth, and

14 CSA (Ethiopia, 2005-2016) data indicate that out of the three-year and older cattle households kept during 2004-2015, the highest proportion of 39.5 percent were kept to provide draft power, with the proportion changing little during the period. A (suspiciously) high proportion (33 percent) were kept for breeding. CSA survey instruments do not include options such as "saving" or "insurance against unexpected cash needs" as coded answers for the question that asks why livestock are kept. Given this, we suspect that some of the households that keep livestock as a means of saving state that they are kept for "breeding." 
FIGURE 5.4 Real value of output per farmer and per tropical livestock unit, 2004-2015

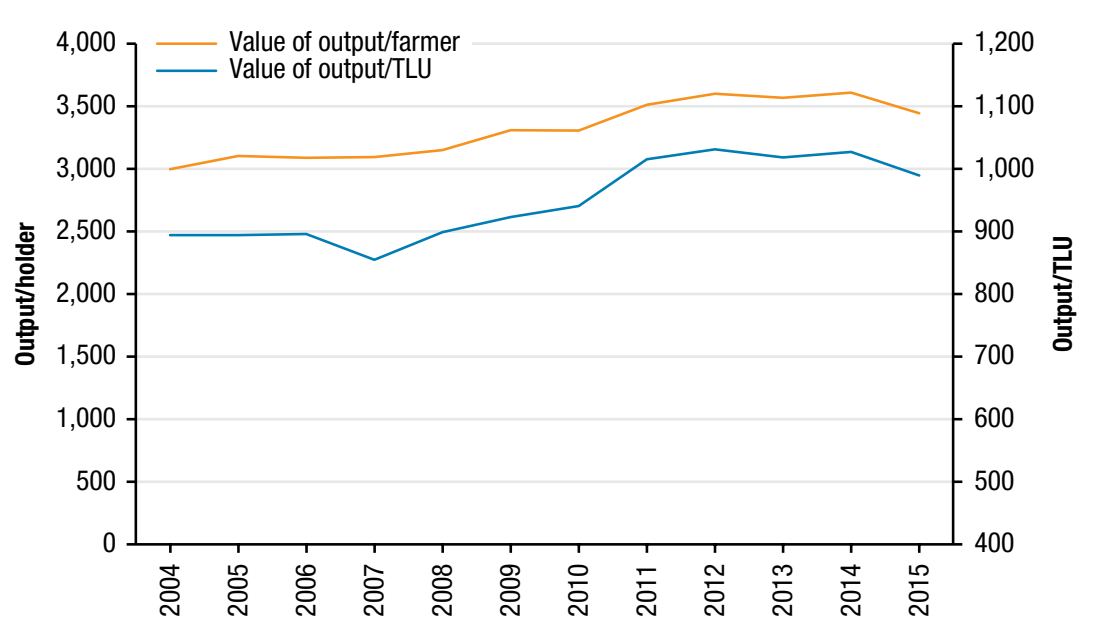

Source: Authors' analyses using real livestock output data from NBE (2017) and CSA data (Ethiopia, CSA 2017, 2005-2016). Note: TLU = tropical livestock unit.

total factor productivity (TFP). The method starts by assuming that markets are competitive and that there exists a well-behaved aggregate livestock production function that expresses real livestock output as a function of inputs used in production and a variable that represents techniques of production. Starting from such a production function and under the assumptions given, the method expresses growth in real livestock output using the formula:

$$
\frac{\Delta O u t p u t}{\text { Output }}=\Delta T F P+\sum_{J} w_{J} \frac{\Delta \text { Input }_{J}}{\text { Input }_{J}}+\alpha \Delta E x o g
$$

where $J$ indexes types of inputs and $w_{J}$ is the relative share or payment to input $J .{ }^{15}$ For instance, if $J$ is labor, $w_{J}$ represents wages paid/imputed for labor used. The equation states that growth in output between two time periods ( $\Delta$ Ouput/Output) is equal to the sum of growths in total payments for all inputs $\left(\Sigma_{J} w_{J} \Delta\right.$ Input $_{J} /$ Input $\left._{J}\right)$; change in exogenous factors that affect livestock production $(\triangle E x o g)$ times the magnitude of the impact of exogenous factors $(\alpha)$; and change in TFP $(\triangle T F P)$, which captures changes in methods of production and the effects of other factors not included in the analyses.

15 Interested readers can see, among others, Solow (1957) and Carlaw and Lipsey (2003). Bachewe et al. (2018) describe the method in the Ethiopian context and apply it to the crop production subsector. 
We conduct the analyses assuming that real livestock output is a function of labor, which we proxy using the total number of livestock farmers. ${ }^{16} \mathrm{We}$ proxy capital using total grazing land and the stock of live animals (TLU); real value of crop output used as livestock feed (used as a proxy for intermediate inputs from the crop subsector); manufacturing sector by-products used as animal feed (used as proxy for intermediate inputs from the manufacturing sector); total number of livestock vaccinated or treated for diseases (used as proxy for intermediate inputs from the services sector); and total number of livestock extension users. We provide a summary of the data used in Appendix Table 5A.1. Furthermore, we derive $w_{\text {J }}$, payments to factors used in production, from the 2005/2006 social accounting matrix for Ethiopia (EDRI 2009), while we follow Bachewe et al. (2018) to approximate the exogenous factors. Note that livestock production may have been affected by other inputs used by farmers, such as crop residues used as animal feed, data on which are unavailable, and by other exogenous factors, such as weather changes. This implies that changes in TFP obtained from the analyses also include the effects of those factors not included in the analyses (Sumner 2014).

We provide the results of the growth accounting analysis in Figure 5.5. This shows the average contribution of the factors considered, expressed as a percentage of real livestock output growth. During the period 2004 to 2014, growth in labor used in livestock production accounted for 2.9 percent of the 5.8 percent average annual growth in real livestock output. That is, growth in labor accounted for almost half-that is, 49 percent-of real livestock output growth. Similarly, growth in TLU contributed 1.5 percent to the total 5.8 percent average annual growth in livestock output - that is, about a quarter of output growth came from growth in the stock of livestock. Growth in improved feed and grazing land together accounted for 18 percent of growth in real livestock output, extension and veterinary services together accounted for 2 percent, and exogenous factors for 5 percent.

The finding that labor and TLU growth combined accounted for 78 percent of the growth in real output and that improved feed, veterinary services, and extension services, which can be considered as modern inputs, accounted for only 11 percent, indicates that most of the livestock output growth resulted from increases in the numbers of livestock and livestock owners (extensive margin) and not through increased use of modern inputs

16 While households constitute the ultimate sampling units in CSA surveys, there can be more than one livestock farmer/holder in a given household. However, the proportion of households with more than one farmer averaged 4 percent and stayed about the same during the period. 
FIGURE 5.5 Average contribution of factors as percentage of livestock output growth

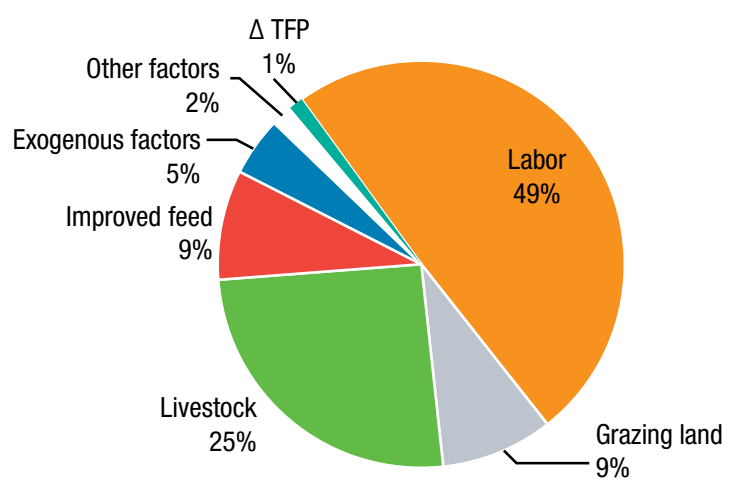

Source: Authors' analyses using real livestock output data from NBE (2017) and CSA data (Ethiopia, CSA 2005-2016, 2017). Note: TFP = total factor productivity.

(intensive margin). Furthermore, changes in TFP accounted for only 1 percent of the growth in output, indicating that almost all the real livestock output growth is accounted for by the factors used in the analyses and that little improvements in methods of livestock production occurred during the period. The growth seen in the livestock sector stands in contrast to growth in the crop sector, in which modern input use and TFP growth were much more important factors in explaining higher output levels (Bachewe et al. 2018). This indicates a lesser role of modernization in explaining recent growth in Ethiopia's livestock sector.

\section{Inputs Used in Livestock Production}

Here we discuss the inputs used in livestock production, including improved breeds, livestock feed, veterinary and livestock extension services, and employment in livestock production.

\section{Improved Livestock Breeds}

We use CSA data to study the breed composition of cows and chickens, the only livestock types for which data are available on breed type. Table 5.7, which summarizes the data on breed type, indicates that indigenous or local breed cows and chickens are dominant. Foreign cow breeds are almost nonexistent among smallholder farmers' herds, while hybrid cows represented only 1 percent and 2 percent of the total number of cows in 2004 and 2015, respectively. A relatively higher percentage of chickens, around 
TABLE 5.7 Breed composition of cows and poultry in Ethiopia, 2004, 2010, and 2015 (\%)

\begin{tabular}{llrcc}
\hline Livestock type & Breed & 2004 & 2010 & $\mathbf{2 0 1 5}$ \\
\hline Cows & Local & 99 & 99 & 98 \\
& Foreign & 0 & 0 & 0 \\
\multirow{4}{*}{ Broiler chickens } & Hybrid & 1 & 1 & 2 \\
& Local & 98 & 97 & 89 \\
& Foreign & 2 & 1 & 6 \\
Egg-laying chickens & Hybrid & 0 & 2 & 5 \\
& Local & 98 & 97 & 89 \\
& Foreign & 2 & 1 & 6 \\
& Hybrid & 0 & 2 & 5 \\
\hline
\end{tabular}

Source: Authors' analyses using CSA holder-level data (Ethiopia, CSA 2017).

11 percent, were foreign and hybrid breeds in 2015, compared to just 2 percent in 2004.

These estimates indicate that effort is needed in this area. However, it is to be noted that artificial insemination is increasingly being adopted in the livestock subsector of Ethiopia. Figure 5.6 shows the evolution in the production, distribution, insemination, pregnancy, and calves born using artificial insemination. The number of calves born using artificial insemination was 11 times higher in 2016 than in 2005 . However, only 230,000 calves were born through artificial insemination in 2016, still a small number compared to the total cattle population.

\section{Animal Feed}

Table 5.8 summarizes CSA data on the proportion of households that used different livestock feed and sources of the feed. Most livestock-owning households use grazing as the principal source of feed for their livestock followed by crop residue. However, the percentage of farmers using green fodder (grazing) as animal feed is declining slowly over time, from 93 percent in 2005 to 90 percent in 2015. The percentage of households that use crop residues remained about the same at 79 percent, while those that used hay slightly increased to 30 percent in 2015 from 27 percent in 2005. But the largest increase, 6.4 percent, occurred in the proportion of households using improved feed-both improved pasture and by-products-from 7.2 percent in 2005 to 13.6 percent in 2015. Most of that increase happened between 2010 and 2015. 
FIGURE 5.6 Artificial insemination of cows, annual doses and outcomes, three-year moving average

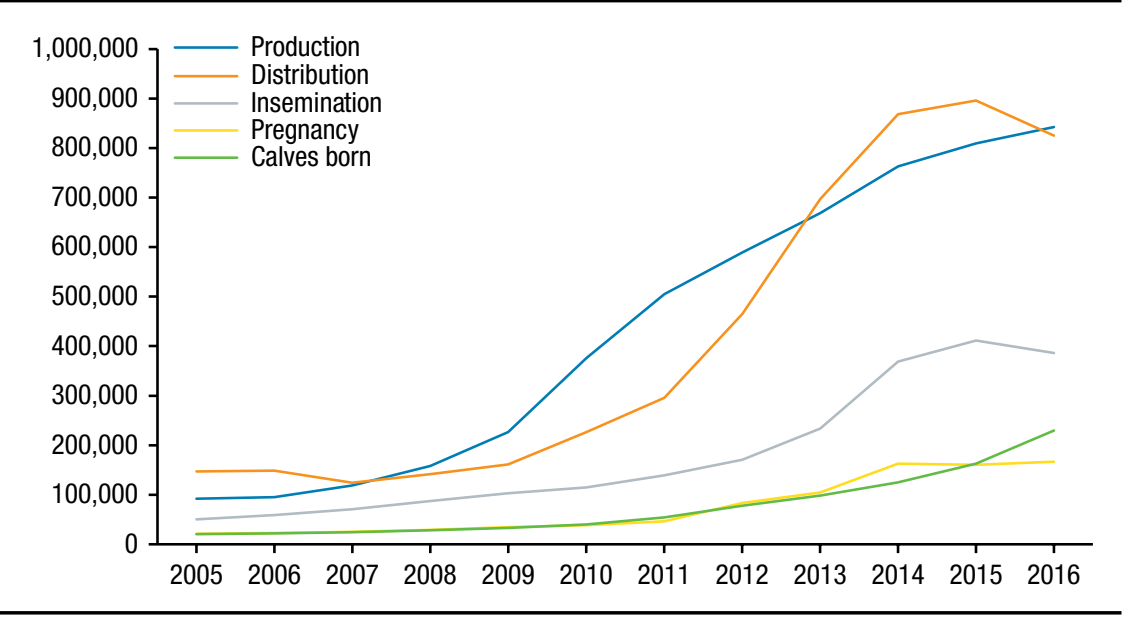

Source: Data from the Ethiopia Ministry of Agriculture and Livestock.

TABLE 5.8 Trends in animal feed type and source of feed, percentage of livestock-owning households, 2005, 2010, and 2015

\begin{tabular}{lccc}
\hline Category & 2005 & 2010 & 2015 \\
\hline Animal feed type & & & \\
Grazing land & 93.3 & 94.1 & 90.5 \\
Crop residue & 78.9 & 80.2 & 78.8 \\
Hay & 27.5 & 32.4 & 30.6 \\
$\quad$ Improved feed & 7.2 & 7.3 & 13.6 \\
Source of feed & & & \\
Own property & 59.1 & 61.5 & 62.1 \\
Purchased & 6 & 6.6 & 7.8 \\
Public property & 17.6 & 15.9 & 11.1 \\
Own property and purchased & 4.7 & 5.2 & 6.2 \\
Own property and public property & 8.9 & 8.5 & 9.7 \\
\hline
\end{tabular}

Source: Authors' computation using CSA data (Ethiopia, CSA 2005-2016).

Most farmers use their own property to acquire livestock feed. In 2015, 62 percent, 11 percent, and 8 percent of households used livestock feed obtained from own property, public property, and purchases, respectively. About 16 percent of the households used feeds acquired from multiple sources. The proportion using purchased feed in 2015 was more than 2 percent higher 
than in 2005, an increase of 30 percent over the period. In contrast, the proportion using public property in 2015 was 37 percent lower than that in 2005. The trends in feed sources observed, which shows a rapid decline in the use of common grazing grounds and an increase in importance of purchased feeds, is consistent with the decline in cultivated area per farmer that occurred during the same period in the country (Minten et al. 2018a). This likely is a result of more of the common grazing grounds of Ethiopia being brought into crop cultivation.

Despite the growth in nationwide agricultural area in the past decade by 2.9 percent per year, landholdings for the average farmer declined by 25 percent (Minten et al. 2018a). A similar pattern was also observed in grazing area. Total grazing area increased from about 1.37 million hectares in 2004 to 1.77 million hectares in 2015. Despite this increase in the aggregate grazing area, average grazing area per farmer in 2015 ( 0.10 hectares) was about 16 percent lower than the average in 2004 ( 0.12 hectares).

\section{Veterinary Services}

A considerable proportion of cattle, small ruminants, and poultry are afflicted by various diseases (Table 5.9). Chickens are the most affected with 57 percent of the stock diseased in 2015, while equines (12.5 percent) and camels (11 percent) are the least affected. Relative to 2004 the percentage of poultry afflicted in 2015 increased by 18 percent, while the increase was between 1 percent and 5 percent for other livestock types.

CSA data also indicate that, of the animals affected by diseases, the proportion that received veterinary services increased in all livestock types during the period (Figure 5.7). In 2015 the percentage of animals treated of those afflicted by disease was the highest for cattle (68 percent) and the lowest for poultry (13 percent). Relative to 2004, the proportion treated for diseases increased in 2015 by about 34 percent for cattle and equines, by 31 percent for sheep, and by 24 percent for goats. The increase was lower for poultry (10 percent) and camels (5 percent). The increase in the proportion of sick animals treated is despite the increase in the proportion afflicted by diseases. This implies that the number of

TABLE 5.9 Trends in livestock afflicted with disease, by livestock type in Ethiopia, 2005, 2010, and 2015 (\%)

\begin{tabular}{lrrr}
\hline Livestock type & $\mathbf{2 0 0 5}$ & $\mathbf{2 0 1 0}$ & $\mathbf{2 0 1 5}$ \\
\hline Cattle & 14.8 & 16.8 & 16.5 \\
Sheep & 17.3 & 26.1 & 20.9 \\
Goats & 18.6 & 23.7 & 20.2 \\
Equines & 10.9 & 13.1 & 12.5 \\
Camels & 12.6 & 6.9 & 11.1 \\
Poultry & 40.9 & 48.7 & 56.8 \\
\hline
\end{tabular}

Source: Authors' analyses using CSA holder level data (Ethiopia, CSA 2017). 
FIGURE 5.7 Trends in livestock afflicted by disease that were treated, by livestock type (\%)

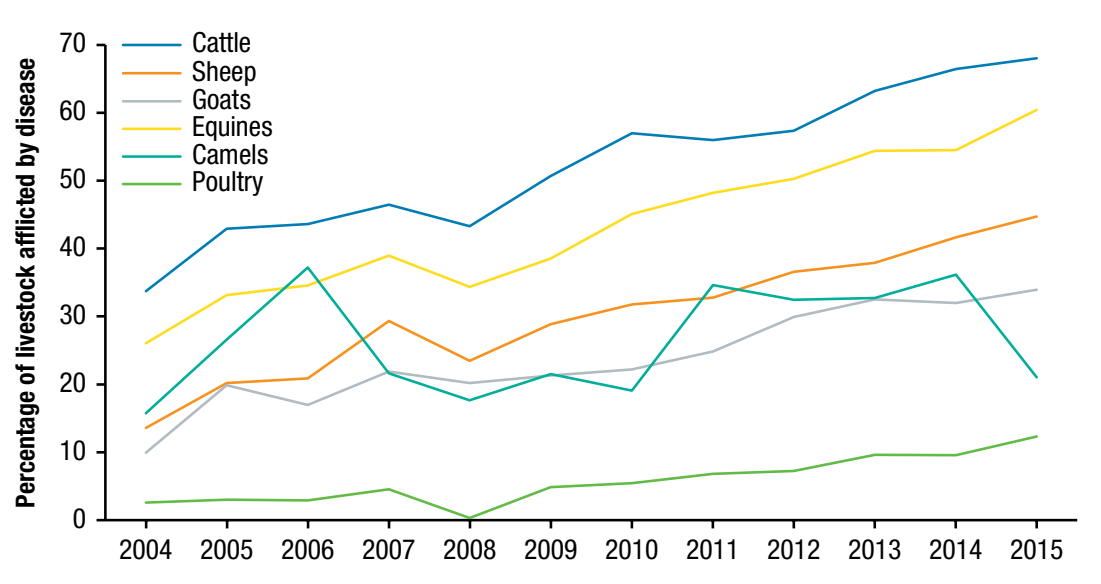

Source: Authors' analyses using CSA holder level data (Ethiopia, CSA 2017).

livestock treated increased faster than the number of sick animals. The data also indicate that the number of treated animals grew faster than the total stock of animals. ${ }^{17}$ These numbers are indicative of the increasing spread of veterinarians and veterinary clinics in the country.

The proportion of livestock vaccinated of total stock also increased considerably for all animal types- 58 percent, 25 percent, 23 percent, and 8 percent of cattle, sheep, goats, and camels, respectively, were vaccinated in 2015 (Figure 5.8). These proportions were 34 percent, 19 percent, 14 percent, and 4 percent higher than the proportions vaccinated in 2004 , respectively. The number of cattle vaccinated in 2015, 33.6 million, was more than three times the number vaccinated in 2004, 9.2 million. Similarly, the number of sheep, goats, and camels vaccinated in 2004 was more than four times the number vaccinated in 2004.

Disease-related animal deaths declined during the period, which may imply a negative relationship between such deaths and the expansion in animal vaccination services (Figure 5.8). ${ }^{18}$ The proportion of cattle afflicted by diseases that died was 28 percent in 2015. The proportion was higher for other

17 The proportion treated out of total stock increased by 5 percent to 7 percent in all livestock types except for camels (1 percent).

18 Disease-related deaths on average accounted for 76 percent to 82 percent of total deaths during 2005-2015 for all livestock types except camels (70 percent). The share of disease-related deaths remained about the same during the period. 
FIGURE 5.8 Proportion of livestock vaccinated and disease-related deaths, 2004/20052015/2016 (\%)
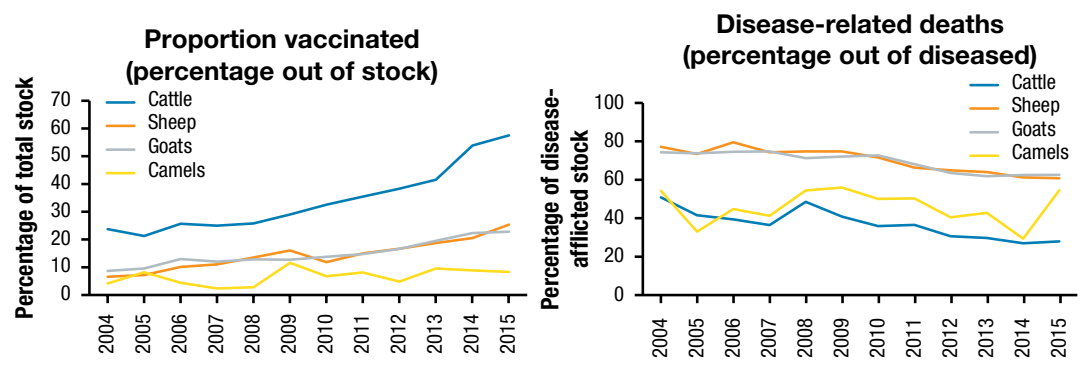

Source: Authors' computation using CSA data (Ethiopia, CSA 2005-2016).

livestock types. Despite the proportion of disease-related deaths being considerable in 2015, they were 23 percent, 16 percent, 12 percent, and 25 percent lower relative to 2005 for cattle, sheep, goats, and equines, respectively.

\section{Livestock Extension}

Extension service provision expanded rapidly in Ethiopia in the past two decades, particularly in the crop subsector. The promotion of modern inputs and production methods through the extension system is cited as one of the contributors to the rapid increase in modern input use and consequent crop production and productivity growth over the past decade (Bachewe et al. 2018; Berhane et al. 2018). However, the extension system has mostly focused on the crop subsector. Table 5.10 shows that only 3 percent and 2 percent of livestock farmers used extension services in 2005 and 2015, respectively. This contrasts to the higher proportion and steady growth in the proportion of farmers using crop extension. The proportion of livestock extension users is also sporadic, which may have resulted from campaign-type extension services provided by programs or projects.

\section{Labor}

The description earlier on the number of livestock owners indicates only the number of households that own livestock and does not represent the number of people actually engaged in such activities as feeding, watering, milking, and providing other care for the animals, which often involve more members of the household than just the head. We use CSA's most recent Labor Force Survey (LFS) data to gauge the contribution of the livestock subsector 
TABLE 5.10 Trends in number of farmers using livestock extension services, 2005, 2010, and 2015

\begin{tabular}{lrrr}
\hline Extension service type & 2005 & 2010 & 2015 \\
\hline All livestock extension & 227,903 & 195,251 & 292,256 \\
Dairy & 37,783 & 48,021 & 57,801 \\
Meat & 29,646 & 56,700 & 45,023 \\
Poultry & 123,736 & 41,626 & 154,967 \\
Honey/wax & 23,172 & 25,336 & 13,329 \\
Two or more & 13,566 & 6,338 & 12,533 \\
Livestock and crop extension users, percentage of farmers (\%) \\
Livestock & 2.9 & 1.4 & 1.9 \\
Crop & 27.5 & 25.5 & 44.3 \\
\hline
\end{tabular}

Source: Authors' computation using CSA data (Ethiopia, CSA 2005-2016).

for nationwide employment. The LFS was conducted in 2013. It included 240,660 persons sampled to represent 80.4 million people residing in all regions and zones of the country, except for six zones in Somali region.

Using the three-digit employment classification used by CSA (Ethiopia, CSA 2014), we identify nine employment types that involve the production and processing of livestock products. This includes livestock farming, mixed crop-livestock farming, processing of animal-sourced food (ASF), and leather processing and manufacturing of leather products. The number of people employed in these sectors accounted for 54.6 percent of the 47.4 million people employed in Ethiopia. The number engaged in mixed crop-livestock production accounted for the largest share ( 46.9 percent), followed by those engaged in only livestock production (7.6 percent). Those engaged in the remaining seven subsectors accounted for less than 0.2 percent of employment nationwide in 2013.

The LFS data do not provide information on the proportion of time/ employment used in livestock production by those engaged in mixed croplivestock production. Thus the contribution of the livestock subsector for employment is imprecise. We can only estimate the contribution of the livestock subsector to national employment patterns. If we assume mixed crop-livestock farmers used between 20 percent and 30 percent of their time for livestock production, then the share of employment in livestock out of total employment in 2013 would be between 17 percent and 22 percent, respectively. These shares are higher than the share of livestock output in real GDP, which was 12.3 percent in 2004 but steadily declined to 7.1 percent in 2015 . 


\section{Correlates of Modern Input Adoption}

Previous discussions indicate that the period 2005-2015 has been marked by rapid growth in the proportion of farmers that use improved feeds, improved cattle and poultry breeds, and livestock vaccinated, although growth for all factors started from a low base. Use levels of these modern inputs are generally still low, and modern inputs contributed little to livestock output growth. This implies that future growth in livestock output needs to be driven by increased use of these and other modern inputs, since the major sources of current output growth, the increases in numbers of farmers and livestock is unsustainable given land scarcity and increasing environmental problems.

Next we discuss the results of analyses conducted to investigate the factors associated with the adoption of the three modern inputs mentioned: improved feed, improved breeds, and vaccination. For this purpose we deploy probit and multinomial probit models on farmer-level CSA data. Average marginal effects obtained from the probit model analyses are provided in Table 5.11, while those obtained using the multinomial probit model are provided in Appendix Table 5A.2. Marginal effects of the analysis on factors associated with adoption of improved feed, data which are collected at the household level, are provided in the second column of Table 5.11. Columns 3 and 4 provide marginal effects of the analyses on factors associated with vaccination of cattle and sheep and goats, respectively. The last two columns of Table 5.11 provide marginal effects of factors associated with the adoption of improved (hybrid or foreign) cattle and poultry breeds. The results in both tables are mostly consistent with expected signs. Moreover, the results pertaining to cattle in Table 5.11 and those in Appendix Table 5A.2 have qualitatively the same implications. Therefore, our discussion below focuses on the results in Table 5.11.

The results indicate that, although all demographic characteristics of farmers appear to be associated with adoption of the three technologies, education and household size are the most important. More educated farmers are more likely to adopt all inputs, which is consistent with the finding for modern input adoption in crop production (Bachewe et al. 2018). Larger-sized households are more likely to adopt all inputs, probably because such households own more labor, which is needed to make the inputs available to or provide the increased care needed by improved breeds.

The likelihood of adopting any of the technologies considered is positively associated with receiving relevant extension advice. That is, the likelihood of having one's livestock vaccinated and the adoption of improved livestock 
TABLE 5.11 Adoption of improved feed, improved livestock breeds, and vaccination in livestock production in Ethiopia-probit model estimates of variables associated with adoption

\begin{tabular}{|c|c|c|c|c|c|}
\hline \multirow[b]{3}{*}{ Variables } & \multirow{3}{*}{$\begin{array}{c}\begin{array}{c}\text { Used } \\
\text { improved } \\
\text { feed? } \\
\text { (yes }=1 \text { ) }\end{array} \\
\begin{array}{c}\text { Farmer } \\
\text { level }\end{array}\end{array}$} & \multicolumn{4}{|c|}{ Dependent variable } \\
\hline & & \multicolumn{2}{|c|}{$\begin{array}{l}\text { Have livestock been } \\
\text { vaccinated? } \\
\text { (yes = 1) }\end{array}$} & \multicolumn{2}{|c|}{$\begin{array}{l}\text { Owned improved breed } \\
\text { of livestock? } \\
\text { (yes = 1) }\end{array}$} \\
\hline & & Cattle & $\begin{array}{l}\text { Sheep and } \\
\text { goats }\end{array}$ & Cattle & Poultry \\
\hline Received extension advice, $0 / 1$ & $0.040^{\star \star *}$ & $0.125^{\star \star \star}$ & $0.071^{\star \star \star}$ & $0.037^{\star \star \star}$ & $0.241^{\star \star \star}$ \\
\hline Average travel time to nearest city (hours) & $-0.000^{\star \star}$ & $-0.002^{\star \star \star}$ & $0.001^{\star \star \star}$ & $-0.002^{\star \star \star}$ & $-0.001^{\star \star \star}$ \\
\hline Age of farm holder (years) & $0.000^{\star \star \star}$ & $0.000^{\star \star \star}$ & $0.000^{\star \star}$ & $0.000^{\star \star \star}$ & -0.000 \\
\hline Farm holder is female, $0 / 1$ & $-0.002^{\star *}$ & $-0.005^{\star \star \star}$ & $0.005^{\star \star \star}$ & 0.000 & -0.002 \\
\hline $\begin{array}{l}\text { Highest educational attainment in house- } \\
\text { hold (years) }\end{array}$ & $0.003^{\star \star \star}$ & $0.009^{\star \star \star}$ & $0.004^{\star \star \star}$ & $0.002^{\star \star *}$ & $0.005^{\star \star \star}$ \\
\hline Household size & $0.003^{\star \star *}$ & $0.007^{\star \star \star}$ & $0.004^{\star \star \star}$ & $0.001^{\star \star \star}$ & $0.002^{\star \star \star}$ \\
\hline Cattle (number) & $0.001^{\star \star *}$ & $0.002^{\star \star \star}$ & & $0.001^{\star \star *}$ & \\
\hline Sheep and goats (number) & $-0.000^{\star}$ & & $0.001^{\star \star \star}$ & & \\
\hline Poultry (number) & $0.001^{\star * *}$ & & & & $0.002^{\star \star \star}$ \\
\hline $\begin{array}{l}\text { Improved feed users in woreda, lagged } \\
\text { percentage }\end{array}$ & Yes & & & & \\
\hline $\begin{array}{l}\text { Vaccinated livestock in woreda, lagged } \\
\text { percentage }\end{array}$ & & Yes & Yes & & \\
\hline $\begin{array}{l}\text { Improved livestock breed in woreda, } \\
\text { lagged percentage }\end{array}$ & & & & Yes & Yes \\
\hline Rainfall and other climate variables & Yes & Yes & Yes & Yes & Yes \\
\hline Average population density & Yes & Yes & Yes & Yes & Yes \\
\hline Year dummies & Yes & Yes & Yes & Yes & Yes \\
\hline Zone dummies & Yes & Yes & Yes & Yes & Yes \\
\hline Chi-squared & 55,418 & 66,782 & 35,993 & 33,586 & 37,363 \\
\hline Observations & 677,985 & 520,216 & 377,885 & 562,964 & 409,217 \\
\hline
\end{tabular}

Source: Authors' analyses.

Note: Table shows (average) marginal effects. Coefficients with ${ }^{\star \star \star}$, ${ }^{\star \star}$, and * are significant at 1 percent, 5 percent, and 10 percent levels, respectively.

breeds are positively associated with receiving extension advice pertaining to each livestock species. Adoption of improved livestock feed is positively associated with receiving one or more of the types of extension advice. These results do not imply that adoption of the inputs can be attributed to extension advice. However, the positive associations imply either that farmers first adopt the inputs and then seek advice or that they may adopt the inputs because of the advice. This, in turn, implies that expansion of livestock extension services 
is likely to be followed by increases in the number of farmers that adopt the inputs, whichever way the causation runs.

Distance to urban centers is negatively associated with adoption of all inputs. This also is consistent with the adoption of modern inputs in crop production, given significant differences in factor and output prices and therefore profitability over space (Bachewe et al. 2018; Vandercasteelen et al. 2018). The results corroborate the evidence that farmers in urban and peri-urban areas and in rural areas closer to major urban centers use improved inputs at higher rates than farmers in remote areas (Minten et al. 2018b).

The results also indicate that larger herd sizes are positively associated with the adoption of all inputs, excluding the negative association of number of sheep and goats and improved feed. These results may imply that farmers with larger herds look for alternative sources to feed all their animals; are likely to own at least one improved breed than those with smaller herds; and will have to vaccinate their herd, given the higher opportunity cost they suffer during disease epidemics.

Adoption of the inputs is also positively influenced by past levels of adoption of the inputs in the woreda (district). This is likely given that higher past adoption rates may imply easier access to the inputs. Moreover, farmers in areas with higher past adoption rates can easily get information about the inputs through neighborhood effects.

\section{Conclusion}

In this chapter we study the performance of the livestock sector in Ethiopia over the past decade. For this we mostly rely on CSA data, which are representative of households engaged in mixed crop-livestock production, by far the largest segment of livestock production systems in the country. ${ }^{19}$ Livestock is important in Ethiopia. We find that almost all farmers in Ethiopia own livestock, and we evaluate the value of livestock stock in the country at US $\$ 11$ billion, or at about US $\$ 720$ per farmer. The largest share of the total value of livestock is from cattle, but this share is coming down, while small ruminants are on the increase, especially in pastoralist areas. Livestock activities are also important for employment, as 55 percent of the population reported at least partial employment in livestock or related sectors. However,

19 This study also covers nonsedentary areas of three zones of Afar and six zones of Somali regions only parenthetically due to data unavailability. This can be taken as a caveat of the study.

However, we make estimates of the importance of pastoralist areas in total livestock production in Ethiopia. 
while Ethiopia recorded rapid economic growth in the past decade, the livestock subsector contributed little to this growth relative to its size, whether measured in terms of employment or of stock of live animals.

Over the past decade, livestock output grew by almost 6 percent annually. Results of a growth accounting analysis indicate that 80 percent of that growth was explained by an increase in numbers of livestock and labor, and not by productivity increases. The number of livestock farmers and the stock of each livestock species was at least 50 percent higher in 2015 than it was in 2004. The growth in the use of modern inputs, such as improved breeds and feeds, and TFP growth was much less important in explaining output growth. This growth path for the livestock sector is in contrast with the crop sector in which modern input use, particularly fertilizer and improved seeds, as well as total factor productivity (TFP) growth played a much more important role in explaining recent growth (Bachewe et al. 2018). Part of the success in the modernization of the crop sector was explained by the increasing presence of extension agents providing advisory services on improved crop production. However, in the livestock subsector, in contrast, farmers' access to livestock extension use has been low and sporadic over the past decade.

While the share of livestock-owning households making use of improved feeds and breeds increased in importance, its level is still low. For example, the number of calves born from cows through artificial insemination increased eleven-fold over the past 10 years, but the technology still accounts for a small share of all calves born in the country. The proportion of all livestock types afflicted with diseases increased during the period studied. However, the proportion of livestock treated for diseases and the proportion vaccinated increased considerably, while a negative relationship between disease-related deaths and vaccination in animals was also observed. Consequently, livestock death rates slightly declined during the period. Nevertheless, a considerable proportion of livestock - higher than twice the proportion sold for meat production-is still lost to unplanned deaths, indicating an important development challenge facing the sector.

The growth by numbers but not in productivity has important implications for feed market use, as the proportion of farmers using purchased feed is increasing, while those grazing their animals on public property is declining, consistent with the decline in grazing area per farmer observed during the period. The growth path in the livestock sector is contrary to what was projected in the Climate Resilient Green Economy (CRGE) plan (Ethiopia 2011), in which it was envisioned that productivity per animal would grow and the 
number of animals would decline. To achieve that vision, it seems that more effort is needed to stimulate productivity growth through improved input use leading to higher productivity levels in the sector. As shown in our adoption analysis, this could possibly be achieved through better livestock extension and service delivery systems, better access to input and output markets for livestock producers, and improved education and awareness levels of farmers owning livestock. A promising avenue for future work would also be an ex-ante evaluation of tradeoffs between investments in livestock versus crop R\&D. Such assessment would be useful given the rapid changes that are happening in demand for livestock products, the past overemphasis on the cereal sector, and the lack of work on $\mathrm{R} \& \mathrm{D}$, and the potential of impact, in the livestock sector. Such analysis might therefore help to potentially inform the rebalancing of these priorities.

\section{Appendix 5A: Variables Used in Growth Accounting, and Average Marginal Effects Regression Estimates}

TABLE 5A.1 Variables used in livestock growth accounting analyses, 2004, 2010, 2014

\begin{tabular}{lrrr}
\hline Variable & $\mathbf{2 0 0 4}$ & \multicolumn{1}{c}{$\mathbf{2 0 1 0}$} & $\mathbf{2 0 1 4}$ \\
\hline Number of livestock holders (million) & 10.3 & 13.9 & 15.0 \\
Grazing area (thousand hectares) & 844.6 & $1,708.6$ & $1,758.5$ \\
Tropical livestock units (million) & 34.5 & 48.7 & 52.4 \\
Value of crop used as animal feed (million birr) & 481.3 & 740.2 & 806.5 \\
Veterinary services (millions of livestock) $^{\text {Number of extension users (thousands) }}$ & 14.6 & 33.8 & 53.7 \\
Rural roads (hundred kilometers) $^{\mathrm{a}}$ & 302 & 195 & 226 \\
Real livestock (billion birr) $^{\mathrm{a}}$ & 18.4 & 29.2 & 32.6 \\
\hline
\end{tabular}

Source: Authors' analyses using CSA data (Ethiopia, CSA 2017, 2005-2016) except those with superscript of (a), which are from NBE (2017). 
TABLE 5A.2 Marginal effects of multinomial probit model estimates of modern input adoption in cattle production in Ethiopia

\begin{tabular}{|c|c|c|c|c|c|c|}
\hline \multirow[b]{2}{*}{ Variables } & \multicolumn{2}{|c|}{ Vaccination } & \multicolumn{2}{|c|}{ Improved breed } & \multicolumn{2}{|c|}{ Both } \\
\hline & $\begin{array}{l}\text { Marginal } \\
\text { effect }\end{array}$ & $\begin{array}{l}\text { Standard } \\
\text { error }\end{array}$ & $\begin{array}{l}\text { Marginal } \\
\text { effect }\end{array}$ & $\begin{array}{l}\text { Standard } \\
\text { error }\end{array}$ & $\begin{array}{l}\text { Marginal } \\
\text { effect }\end{array}$ & $\begin{array}{l}\text { Standard } \\
\text { error }\end{array}$ \\
\hline Received extension advice, $0 / 1$ & $0.087^{\star \star \star}$ & 0.0066 & $0.018^{\star \star \star}$ & 0.0008 & $0.018^{\star \star \star}$ & 0.0006 \\
\hline $\begin{array}{l}\text { Average travel time to nearest city } \\
\text { (hours) }\end{array}$ & $-0.001^{\star \star \star}$ & 0.0003 & $-0.001^{\star \star \star}$ & 0.0001 & $-0.001^{\star \star \star}$ & 0.0001 \\
\hline Age of farm holder (years) & $0.000^{\star \star \star}$ & 0.0000 & $0.000^{\star \star \star}$ & 0.0000 & $0.000^{\star \star \star}$ & 0.0000 \\
\hline Farm holder is female, $0 / 1$ & $-0.005^{\star \star \star}$ & 0.0016 & -0.000 & 0.0004 & 0.000 & 0.0003 \\
\hline Highest educational attainment (years) & $0.007^{\star \star \star}$ & 0.0002 & $0.001^{\star \star \star}$ & 0.0000 & $0.001^{\star \star \star}$ & 0.0000 \\
\hline Household size & $0.005^{\star \star \star}$ & 0.0003 & $0.001^{\star \star *}$ & 0.0001 & $0.001^{\star \star \star}$ & 0.0000 \\
\hline Cattle (number) & $0.002^{\star \star *}$ & 0.0001 & $0.000^{\star \star \star}$ & 0.0000 & $0.000^{\star \star \star}$ & 0.0000 \\
\hline $\begin{array}{l}\text { Vaccinated cattle in woreda, lagged } \\
\text { percent }\end{array}$ & $0.003^{\star \star \star}$ & 0.0000 & $-0.000^{\star \star \star}$ & 0.0000 & $0.000^{\star \star \star}$ & 0.0000 \\
\hline $\begin{array}{l}\text { Improved cattle breed in woreda, } \\
\text { lagged percent }\end{array}$ & -0.000 & 0.0001 & $0.001^{\star \star \star}$ & 0.0000 & $0.000^{\star \star \star}$ & 0.0000 \\
\hline Rainfall and other climate variables & \multicolumn{2}{|c|}{ Yes } & \multicolumn{2}{|c|}{ Yes } & \multicolumn{2}{|c|}{ Yes } \\
\hline Average population density & \multicolumn{2}{|c|}{ Yes } & \multicolumn{2}{|c|}{ Yes } & \multicolumn{2}{|c|}{ Yes } \\
\hline Year dummies & \multicolumn{2}{|c|}{ Yes } & \multicolumn{2}{|c|}{ Yes } & \multicolumn{2}{|c|}{ Yes } \\
\hline Zone dummies & \multicolumn{2}{|c|}{ Yes } & \multicolumn{2}{|c|}{ Yes } & \multicolumn{2}{|c|}{ Yes } \\
\hline Chi-squared & \multicolumn{6}{|c|}{84,491} \\
\hline Observations & \multicolumn{6}{|c|}{572,336} \\
\hline
\end{tabular}

Source: Authors' analyses.

Note: Table shows average marginal effects. Coefficients with ${ }^{\star \star \star},{ }^{\star \star}$, and ${ }^{\star}$ are significant at 1 percent, 5 percent, and 10 percent levels, respectively.

\section{References}

AACCSA (Addis Ababa Chamber of Commerce and Sectoral Associations). 2015. Value Chain Study on Meat Processing Industry in Ethiopia. Accessed April 15, 2015. http://addischamber .com/wp-content/uploads/2017/01/Value-Chain-study-on-Meat-Processing.pdf.

- 2016. Value Chain Study on Dairy Industry in Ethiopia. Accessed April 15, 2015. http:// addischamber.com/wp-content/uploads/2017/01/Value-chain-study-on-Dairy-industry-in -Ethiopia.pdf.

Aklilu, Y., and A. Catley. 2010. Mind the Gap: Commercialization, Livelihoods and Wealth Disparity in Pastoralist Areas of Ethiopia. Project report. Somerville, MA, US: Feinstein International Center of the Friedman School of Nutrition Science and Policy, Tufts University. Accessed June 2, 2018. http://fic.tufts.edu/assets/mind-the-gap.pdf. 
Anteneh, B., A. Tegegne, F. Beyene, and B. Gebremedhin. 2010. Cattle Milk and Meat Production and Marketing Systems and Opportunities for Market-Orientation in Fogera Woreda, Amhara Region, Ethiopia. Improving Productivity and Market Success of Ethiopian Farmers Project Working Paper 19. Nairobi: International Livestock Research Institute.

Bachewe, F., G. Berhane, B. Minten, and A. S. Taffesse. 2018. "Agricultural Transformation in Africa? Assessing the Evidence in Ethiopia.” World Development 105: 286-298.

Barrett, C., S. Osterloh, P. D. Little, and J. G. McPeak. 2004. Constraints Limiting Marketed Off-Take Rates among Pastoralists. Research Brief 04-06-PARIMA. Global Livestock Collaborative Research Support Program. Davis, CA, US: University of California.

Berhane, G., C. Ragasa, G. Abate, and T. W. Assefa. 2018. The State of Agricultural Extension Services in Ethiopia and Their Contribution to Agricultural Productivity. IFPRI-ESSP Working Paper 118. Addis Ababa: IFPRI/ESSP.

Carlaw, K., and R. G. Lipsey. 2003. "Productivity, Technology, and Economic Growth: What Is the Relationship?" Journal of Economic Surveys 17 (3): 457-495.

EDRI (Ethiopian Development Research Institute). 2009. Ethiopia: Input-Output Table and Social Accounting Matrix. Addis Ababa.

Ethiopia. 2011. Ethiopia’s Climate-Resilient Green Economy: Green Economy Strategy. Addis Ababa. Accessed September 11, 2019. www.undp.org/content/dam/ethiopia/docs/Ethiopia\%20 CRGE.pdf.

Ethiopia, CSA (Central Statistical Agency). 2005-2016. Agricultural Sample Survey Volume 2: Report on Livestock and Livestock Characteristics (Private Peasant Holdings, Meher Season). Addis Ababa.

—. 2017. Agricultural Sample Survey: Holder Level Data of Livestock and Livestock Characteristics (Private Peasant Holdings, Meher Season). Addis Ababa.

FAO (Food and Agriculture Organization of the United Nations). 2018. FAOSTAT database. Accessed January 13, 2019. http://faostat.fao.org/.

Legesse, G., H. Teklewold, D. Alemu, and A. Negassa. 2008. Live Animal and Meat Export Value Chains for Selected Areas in Ethiopia. Constraints and Opportunities for Enhancing Meat Exports. Improving Market Opportunities. Discussion Paper 12. Nairobi: International Livestock Research Institute.

Lybbert, T. J., F. B. Galarza, J. McPeak, C. B. Barrett, S. R. Boucher, M. R. Carter, S. Chantarat, A. Fadlaoui, and A. Mude. 2010. "Dynamic Field Experiments in Development Economics: Risk Valuation in Morocco, Kenya and Peru." Agricultural and Resource Economics Review 39 (2): $1-17$.

Minten, B., M. Dereje, F. Bachewe, and S. Tamru. 2018a. Evolving Food Systems in Ethiopia. IFPRI-ESSP Working Paper 117. Addis Ababa: IFPRI/ESSP. 
Minten, B., Y. Habte, S. Tamru, and A. Tesfaye. 2018b. Transforming Agri-food Systems in Ethiopia: Evidence from the Dairy Sector. IFPRI-ESSP Working Paper 129. Addis Ababa: IFPRI/ESSP. NABC (Netherlands Africa Business Council). 2011. Poultry in Ethiopia: A Survey of Production, Value Chains and Marketing of Commercial Poultry in Ethiopia. The Hague, Netherlands. Accessed June 2, 2018. https://nabc.nl/uploads/content/files/NABC_poultryrapport\%20 Ethiopia.pdf.

NBE (National Bank of Ethiopia). 2017. Annual Report 2015/16. Addis Ababa.

Negassa, A., and M. Jabbar. 2008. Livestock Ownership, Commercial Off-take Rates and Their Determinants in Ethiopia. ILRI Research Report 9. Nairobi: International Livestock Research Institute.

Negassa, A., S. Rashid, and B. Gebremedhin. 2011. Livestock Production and Marketing. Ethiopia Strategy Support Program II Working Paper 26. Addis Ababa: IFPRI/ESSP.

Oqubay, A. 2015. Made in Africa: Industrial Policy in Ethiopia. New York: Oxford University Press.

Shapiro, B. I., G. Gebru, S. Desta, A. Negassa, K. Nigussie, G. Aboset, and H. Mechal. 2015. Ethiopia Livestock Master Plan. ILRI Project Report. Nairobi, Kenya: International Livestock Research Institute (ILRI).

Solomon, A., A. Workalemahu, M. A. Jabbar, M. M. Ahmed, and H. Belachew. 2003. Livestock Marketing in Ethiopia: A Review of Structure, Performance and Development Initiatives. Socio-economics and Policy Research Working Paper 52. Addis Ababa: Livestock Marketing Authority.

Solow, R. M. 1957. "Technical Change and the Aggregate Production Function." Review of Economics and Statistics 39: 312-320.

Sumner, D. A. 2014. “American Farms Keep Growing: Size, Productivity and Policy.” Journal of Economic Perspectives 28 (1): 147-166.

Tafere, K., and I. Worku. 2012. Consumption Patterns of Livestock Products in Ethiopia: Elasticity Estimates Using HICES (2004/05) Data. IFPRI-ESSP Working Paper 12. Addis Ababa: IFPRI/ESSP.

Tamirat, M. 2013. "Econometric Estimation of Herd Stocking Decisions in South Ethiopia." Journal of Development and Agricultural Economics 5 (8): 321-327.

Vandercasteelen, J., S. Tamru, B. Minten, and J. Swinnen. 2018. "Cities and Agricultural Transformation in Africa: Evidence from Ethiopia." World Development 105 (May): 383399. https://doi.org/10.1016/j.worlddev.2017.10.032. 